\title{
ANALISIS TAHAP PEMBUKTIKAN TEOREMA STEWART PADA MAHASISWA PROGRAM STUDI PENDIDIKAN MATEMATIKA UNIVERISTAS KATOLIK WIDYA MANDALA MADIUN
}

\author{
Vigih Hery Kristanto \\ Program Studi Pendidikan Matematika, Universitas Katolik Widya Mandala Madiun; \\ Jl. Manggis, 15-17, Madiun, Jawa Timur, (0351)453328 \\ e-mail: vigihhery@gmail.com
}

\begin{abstract}
Abstrak. Tujuan dalam penelitian ini adalah untuk mengetahui tahap pembuktian teorema Stewart yang dilakukan oleh mahasiswa Prodi Pendidikan Matematika Universitas Katolik Widya Mandala Madiun. Jenis penelitian ini adalah penelitian kualitatif dengan analisis data secara deskriptif. Banyaknya subyek penelitian terdiri dari tiga mahasiswa. Penelitian ini mendeskripsikan tahap pembuktian teorema Stewart yang dilakukan oleh mahasiswa. Proses pengumpulan data diawali dengan subyek diminta untuk membuktikan teorema Stewart dan menuliskan proses pembuktian teorema Stewart pada lembar jawaban yang disediakan. Dari hasil pengumpulan data diperoleh bahwa proses pembuktian yang dilakukan oleh ketiga mahasiswa tersebut menggunakan metode pembuktian langsung, terdapat beberapa kesamaan ketiga mahasiswa dalam mengawali proses pembuktian, yaitu: menggambar garis tinggi pada segitiga dan menggunakan teorema pythagoras untuk menambah informasi yang digunakan dalam proses pembuktian, untuk membuktikan teorema Stewart dibutuhkan ketelitian pada saat menguraikan suatu bentuk aljabar dan pemahaman terhadap konsep aljabar dari bilangan, untuk membuktikan teorema Stewart dibutuhkan waktu yang sesuai dengan kecepatan berpikir yang membuktikan, untuk membuktikan teorema Stewart dibutuhkan keterampilan pemecahan masalah, pemikiran logis, kritis, analitis dan sistematis. Dengan demikian dapat disimpulkan bahwa, secara garis besar langkah-langkah pembuktian teorema Stewart yang dilakukan oleh mahasiswa Program Studi Pendidikan Matematika, dimulai dengan menggambar segitiga ABC dan menggambarkan pula garis bantu (garis tinggi CE), mengumpulkan informasi-informasi yang digunakan dalam proses pembuktian, kemudian menggunakan informasi-informasi yang diperoleh untuk menguraikan bentuk ruas kanan dari persamaan $C D^{2} \cdot A B=B C^{2} \cdot A D+A C^{2} \cdot B D-A D \cdot B D \cdot A B$ menjadi ruas kiri, sehingga persamaan tersebut berlaku.
\end{abstract}

Kata Kunci: Analisis, Pembuktian, Teorema, Stewart

\begin{abstract}
The purpose of this research was to find out how the stage of proofing the Stewart theorem was conducted by students of the Mathematics Education Department at Catholic Widya Mandala University of Madiun. This type of research is qualitative research with descriptive data analysis. The number of research subjects consisted of three students. This study describes the stage of proofing Stewart's theorem by students. The data collection process begins with the subject being asked to prove Stewart's theorem and write down the process of proving Stewart's theorem on the answer sheet provided. From the results of data collection, it was found that the verification process carried out by the three students used the direct verification method, there were some similarities between the three students in initiating the verification process, namely: drawing a high line on a triangle and using the pythagoras theorem to add information used in the verification process, to proving that Stewart's theorem required precision when describing an algebraic form and understanding of algebraic concepts from numbers, to prove Stewart's theorem needed time according to the speed of thinking that proves, to prove the Stewart theorem required problem solving skills, logical thinking, critical, analytical and systematic. Thus it can be concluded that, in general the steps of proving Stewart's theorem carried out by students of the Mathematics Education Department, starting with drawing ABC triangles and also describing auxiliary lines (high of $\mathrm{CE}$ ), collecting information used in the verification process, then use the information obtained to describe the shape of the right side of the equation $C D^{2} \cdot A B=B C^{2} \cdot A D+A C^{2} \cdot B D-A D \cdot B D \cdot A B$ becomes the left hand side, so that the equation applies.
\end{abstract}

Keyword: Analysis, Proof, Theorem, Stewart 


\section{Pendahuluan}

Pengetahuan adalah modal dasar untuk mencapai kemajuan kehidupan manusia. Pengetahuan dapat diperoleh salah satunya dengan penelitian dan eksplorasi, dua proses ini membutuhkan waktu yang lama. Dalam kajian matematika, eksplorasi yang dilakukan berlandaskan pada abstraksi dan simbolisasi dengan menetapkan aksioma, definisi dengan menyusun formulasi konjektur (dugaan). Deduksi secara taat azas (rigorous) berdasarkan penalaran untuk menyatakan kebenaran dugaan, serta membangun teorema. Membangun teorema merupakan salah satu hal penting dalam sebuah proses eksplorasi, tanpa teorema pekerjaan menjadi lebih sulit dan proses eksplorasi akan terhenti pada suatu kondisi tertentu. Namun sebelum digunakan, suatu teorema harus dibuktikan terlebih dahulu kebenarannya. Menurut Julan Hernadi, orang perlu membuktikan suatu pernyataan matematika karena suatu pembuktian dapat memberikan keyakinan bahwa apa yang selama ini dianggap benar adalah benar (Hernadi, 2012). Dalam matematika suatu konsep pangkal disebut dengan aksioma, aksioma merupakan pernyataan-pernyataan yang telah disepakati kebenarannya. Dengan menggunakan aksioma inilah diturunkan teorema-teorema yang harus dibuktikan kebenarannya menggunakan logika matematika (Kristanto, 2011).

Selain itu, pembuktian suatu teorema dapat memberikan pemahaman kepada yang membuktikan dan melatih yang membuktikan teorema tersebut untuk berpikir analitis, kritis, logis, dan sistematis. Keterampilan-keterampilan berpikir tersebut merupakan modal dasar bagi seseorang untuk dapat hidup dan menyelesaikan permasalahan dalam kehidupannya. Salah satu bidang kajian matematika yang sangat erat hubungannya dengan kehidupan adalah geometri. Geometri Merupakan cabang matematika yang mengkaji ukuran, bentuk permukaan (shape), bentuk bangun, dan posisinya dalam ruang observasi. Ini sesuai dengan penggunaan awal geometri, yaitu penyelidikan bumi dan ukurannya. Bidang ini merupakan sains tertua, pada awalnya mengkaji ukuran panjang, luas, dan volume dari bangun-bangun tertentu termasuk di dalamnya bidang astronomi yang mengkaji letak dan peredaran planet-planet dalam jagad raya. Oleh karena itu, memahami teorema dalam geometri menjadi keharusan, khususnya bagi mahasiswa Program Studi pendidikan matematika. Hal ini dikarenakan mereka nantinya menjadi guru matematika yang akan membelajarkan siswa menggunakan konsep Geometri untuk menyelesaikan masalah dalam kehidupan.

Dalam geometri terdapat banyak teorema yang dapat dipelajari, salah satunya adalah teorema Stewart. Teorema Stewart digunakan untuk menentukan ukuran panjang suatu garis yang ditarik dari salah satu titik sudut segitiga ke sisi di hadapan sudut tersebut. Selain itu, teorema Stewart ini juga yang menjadi dasar dalam menentukan panjang suatu garis berat dari segitiga. Pada sebarang segitiga, panjang garis yang dibuat dari salah satu titik sudut suatu segitiga ke sisi dihadapannya dapat dihitung. Namun, untuk menghitung garis tersebut, panjang setiap sisi segitiga dan bagian-bagian sisi yang terpotong oleh garis tersebut harus diketahui. Untuk lebih memperjelas, di bawah ini digambarkan sebarang segitiga ABC. 


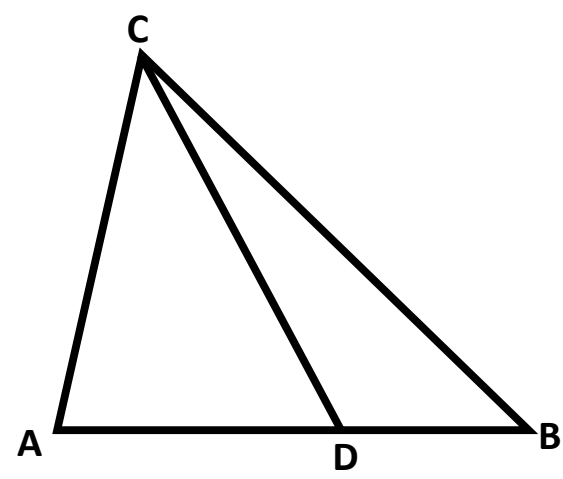

\section{Gambar 1. Segitiga ABC dengan CD sebarang}

Terlihat pada gambar 1, dibuat garis dari titik $\mathrm{C}$ dan memotong sisi $\mathrm{AB}$ dari segitiga $\mathrm{ABC}$ di titik D. Panjang garis $\mathrm{CD}$ dapat dihitung, dengan syarat panjang sisi $\mathrm{AB}, \mathrm{BC}, \mathrm{AC}$ dan bagian-bagian perpotongan $\mathrm{CD}$ dengan $\mathrm{AB}$ yaitu $\mathrm{AD}$ dan $\mathrm{DB}$ diketahui. Untuk menghitung panjang CD dengan syarat seperti di atas digunakan teorema Stewart. Teorema Stewart berbunyi, "kuadrat suatu garis yang ditarik dari sebuah titik sudut segitiga ke sisi dihadapannya, dikalikan dengan sisi tersebut sama dengan jumlah kuadrat dua sisi yang lain dan masing-masing dikalikan dengan bagian sisi ketiga yang tidak bersebelahan letaknya dan dikurangi dengan perkalian dari bagian-bagian itu dengan sisi tersebut". Jika dituliskan dalam bentuk matematis berdasarkan gambar 1, maka teorema Stewart di atas menjadi:

$$
C D^{2} \times A B=B C^{2} \times A D+A C^{2} \times B D-A D \times B D \times A B
$$

Bunyi teorema Stewart di atas, dapat dinyatakan dalam bentuk implikasi jika p maka $\mathrm{q}$ ( $\mathrm{p} \Rightarrow \mathrm{q}$ ) yaitu, jika pada sisi $\mathrm{AB}$ dari sebuah segitiga $\mathrm{ABC}$ terletak titik $\mathrm{D}$, maka:

$$
C D^{2} \times A B=B C^{2} \times A D+A C^{2} \times B D-A D \times B D \times A B
$$

Bentuk implikasi dari teorema Stewart di atas menyatakan bahwa, jika pada sisi $\mathrm{AB}$ pada suatu segitiga $A B C$ terdapat titik $D$, maka panjang $C D$ dapat dihitung menggunakan persamaan yang telah diuraikan di atas. Karena teorema Stewart dapat dinyatakan dalam bentuk implikasi, sehingga untuk membuktikan teorema tersebut dapat menggunakan metodemetode pembuktian matematika. Terdapat berbagai macam jenis metode pembuktian dalam matematika. Namun, metode pembuktian apapun memiliki prinsip dasar serupa, yaitu membuktikan kebenaran dari suatu pernyataan. Dalam menentukan nilai kebenaran suatu pernyataan matematika digunakan dua dasar pemikiran yaitu, dasar empiris dan dasar tak empiris. Dalam dasar empiris dalam penentuan benar atau salah dari sebuah pernyataan berdasarkan pada fakta yang ada atau dijumpai dalam kehidupan sehari-hari. Dalam dasar tak empiris penentuan benar atau salah dari sebuah pernyataan dengan memakai bukti atau perhitungan-perhitungan dalam matematika (Arieyantini, 2013).

Sebagai contoh pernyataan dalam teorema kerapatan, "if $x$ and $y$ are real number with $x$ $<y$, then there exist a rational number $r$ such that $x<r<y$ " (Bartle, 1994). Teorema kerapatan tersebut dapat dibuktikan dengan tahap-tahap sebagai berikut. 
Perhatikan bahwa $\frac{1}{y-x}$ adalah bilangan positif $(\mathrm{x}<\mathrm{y})$. Menurut sifat Archimedes terdapat bilangan asli $\mathrm{n}$ sedemikian sehingga $\mathrm{n}>\frac{1}{y-x}$. Akibatnya untuk nilai $\mathrm{n}$ tersebut berlaku:

$n y-n x>1 \ldots$ (i)

Diambil sebarang bilangan bulat pertama yang lebih dari $\mathrm{nx}$, yaitu: $\mathrm{m}$ dan berlaku:

$m-1 \leq n x<m \ldots$ (ii)

Dari (i) dan (ii) diperoleh:

$n x<m<n x+1<n y$ atau $n x<m<n y$

Sehingga jika $n x<m<n y$ dibagi dengan $\mathrm{n}$, maka diperoleh bentuk $x<\frac{m}{n}<y$. Misalkan $\frac{m}{n}=r$, pembuktian selesai.

Contoh lain, misalnya pernyataan, "tunjukkan bahwa $2^{n}>n^{3}$, jika $n \geq 10$ ! (Liu, 1995). Pernyataan tersebut dapat dibuktikan dengan tahapan sebagai berikut.

Pembuktian dengan induksi matematika, yaitu: (1) langkah dasar, (2) langkah induktif. Untuk membuktikan contoh tersebut, pertama kita menggunakan langkah dasar. (1) Untuk $\mathrm{n}=10$, diperoleh: $2^{10}=1024>10^{3}=1000$. Sehingga untuk $\mathrm{n}=10$ contoh soal di atas benar. (2) Asumsikan contoh di atas, berlaku untuk $n=k$, sehingga diperoleh: $2^{k}>$ $\mathrm{k}^{3}$. Kemudian akan dibuktikan bahwa bentuk tersebut juga berlaku untuk $\mathrm{n}=\mathrm{k}+1$.

$$
\begin{aligned}
2^{k+1}=2 \cdot 2^{k}>\left(1+\frac{1}{10}\right)^{3} \cdot 2^{k} & \geq\left(1+\frac{1}{k}\right)^{3} \cdot 2^{k} \\
& >\left(1+\frac{1}{k}\right)^{3} \cdot k^{3}=(k+1)^{3}
\end{aligned}
$$

Karena bentuk $2^{\mathrm{n}}>\mathrm{n}^{3}$ berlaku untuk $\mathrm{n}=\mathrm{k}+1$, sehingga $2^{\mathrm{n}}>\mathrm{n}^{3}$, jika $\mathrm{n} \geq 10$ berlaku untuk semua bilangan asli $n$.

Teorema Stewart disampaikan dalam matematika sekolah, tepatnya pada jenjang SMP kelas VIII kurikulum KTSP. Sebagai calon guru matematika maka bagi mahasiswa Program Studi pendidikan matematika teorema ini menjadi salah satu kompetensi yang harus dikuasai. Dengan demikian, dengan mengetahui tahap pembuktian Teorema Stewart, wawasan dan pemahaman mahasiswa subyek penelitian dapat meningkat. Dari semua uraian di atas, maka terlihat dengan jelas betapa pentingnya mempelajari pembuktian teorema dan memahami teorema dalam kajian geometri, khususnya teorema Stewart. Oleh sebab itu peneliti menuliskan sebuah kajian yang berjudul,"Analisis Tahap Pembuktian Teorema Stewart".

\section{Metode Penelitian}

Penelitian ini dilaksanakan di Universitas Katolik Widya Mandala Madiun, Jl. Manggis, No. 15-17, Kota Madiun. Penelitian ini dilaksanakan selama satu hari, yaitu pada hari Jum'at, 17 Juni 2011. Jenis penelitian ini adalah penelitian kualitatif dengan analisis data secara deskriptif. Penelitian ini nantinya akan mendeskripsikan tahap pembuktian teorema Stewart yang dilakukan oleh mahasiswa. Dengan demikian subyek dalam penelitian ini adalah mahasiswa Program Studi Pendidikan Matematika semester VI tahun akademik 2010-2011. Mahasiswa yang dipilih sebagai subyek penelitian memiliki indeks prestasi akademik kumulatif (IPK) heterogen. Selain itu, kemampuan mahasiswa tersebut dalam Mata Kuliah Geometri juga heterogen. 
Di Program Studi Pendidikan Matematika, mahasiswa semester VI sebanyak 19 mahasiswa dan dipilih sebagai subyek penelitian sebanyak tiga mahasiswa. Hal ini dilakukan dengan pertimbangan bahwa penelitian ini tidak termasuk penelitian dalam skala besar, sehingga tiga mahasiswa sebagai subyek penelitian sudah cukup. Selain itu, peneliti mempunyai berbagai macam keterbatasan. Tiga mahasiswa yang terpilih dalam penelitian ini dicantumkan dalam tabel sebagai berikut:

Tabel 1. Daftar Mahasiswa Subyek Penelitian

\begin{tabular}{clcc}
\hline No & & Inisial & IPK terakhir \\
\hline 1. & YH & 3,69 \\
2. & H & 3,42 \\
3. & DF & 2,91 \\
\hline
\end{tabular}

Langkah-langkah yang dilakukan oleh peneliti pada penelitian ini adalah membuat dasar pemikiran tentang pentingnya melakukan penelitian, mengkaji teori-teori yang berkaitan dengan penelitian, memilih subyek penelitian, menyusun instrumen penelitian, melaksanakan penelitian (pengumpulan data penelitian), pelaporan hasil penelitian, dan publikasi hasil penelitian. Proses pengumpulan data untuk kepentingan analisis pada penelitian ini adalah subyek diminta untuk membuktikan teorema Stewart dan menuliskan proses pembuktian teorema Stewart pada lembar jawaban yang disediakan. Sehingga data yang terkumpul dalam bentuk dokumen. Dokumen yang dimaksud adalah lembar jawaban yang telah diisi oleh subyek penelitian. Instrumen yang digunakan untuk mengumpulkan data pada penelitian ini adalah lembar soal beserta lembar jawaban. Pada saat pengumpulan data, dilakukan perekaman menggunakan kamera CCTV untuk mencegah kecurangan subyek dalam membuktikan teorema. Hal ini dikarenakan pada saat menentukan pembuktian teorema Stewart, subyek bekerja dalam waktu dan ruangan yang sama.

\section{Hasil Pembahasan dan Penelitian}

\section{Salah Satu Langkah Pembuktian Teorema Stewart}

Untuk membuktikan teorema Stewart terlebih dahulu dapat digambarkan sebuah garis bantu pada segitiga ABC. Misalkan dibuat garis $C E$ sebagai tinggi segitiga $A B C$, karena $C E$ merupakan tinggi segitiga $\mathrm{ABC}$, maka garis $\mathrm{CE}$ tegak lurus dengan garis $\mathrm{AB}$. Keadaan tersebut digambarkan sebagai berikut. 


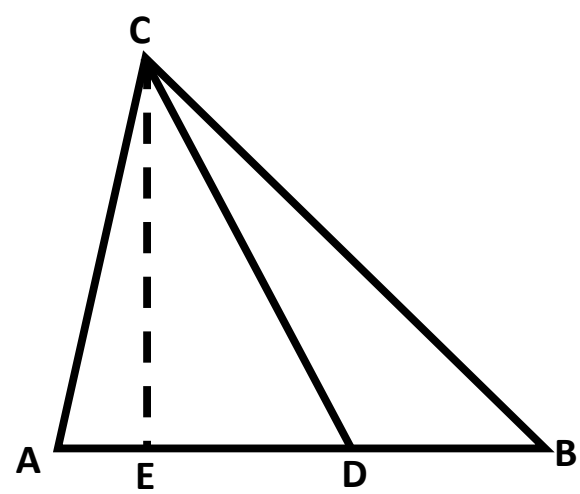

\section{Gambar 2. Segitiga ABC dengan CD sebarang dan CE garis tinggi}

Dengan ditambahkannya garis bantu $\mathrm{CE}$ pada segitiga $\mathrm{ABC}$, sehingga diperoleh segitiga siku-siku CED. Karena CED segitiga siku-siku, maka dapat digunakan teorema pythagoras pada panjang sisi segitiga CED, sebagai berikut:

$$
\mathrm{CE}^{2}=\mathrm{CD}^{2}-\mathrm{DE}^{2} \ldots \text { (i). }
$$

Kemudian dari segitiga ADC, diperoleh sebuah hubungan:

$$
\mathrm{AC}^{2}=\mathrm{AE}^{2}+\mathrm{CE}^{2} \text {. }
$$

Terlihat bahwa panjang $\mathrm{AE}=\mathrm{AD}-\mathrm{DE}$, sehingga bentuk di atas menjadi:

$$
\mathrm{AC}^{2}=\mathrm{CE}^{2}+(\mathrm{AD}-\mathrm{DE})^{2} \ldots \text { (ii). }
$$

Selanjutnya persamaan (i) disubstitusikan ke dalam persamaan (ii), sehingga didapatkan sebuah persamaan berbentuk:

$$
\begin{aligned}
& \mathrm{AC}^{2}=\mathrm{CD}^{2}-\mathrm{DE}^{2}+(\mathrm{AD}-\mathrm{DE})^{2} \\
& \mathrm{AC}^{2}=\mathrm{CD}^{2}-\mathrm{DE}^{2}+\mathrm{AD}^{2}-2 . \mathrm{AD} . \mathrm{DE}+\mathrm{DE}^{2} \\
& \mathrm{AC}^{2}=\mathrm{CD}^{2}+\mathrm{AD}^{2}-2 . \mathrm{AD} . \mathrm{DE} \ldots \text { (iii) }
\end{aligned}
$$

Dari penjabaran di atas, diperoleh persamaan (iii). Selanjutnya, dari segitiga siku-siku $\mathrm{BCE}$ menggunakan teorema pythagoras diperoleh persamaan:

$\mathrm{BC}^{2}=\mathrm{CE}^{2}+\mathrm{BE}^{2}$,

terlihat bahwa panjang $\mathrm{BE}=\mathrm{BD}+\mathrm{DE}$, sehingga persamaan di atas menjadi:

$\mathrm{BC}^{2}=\mathrm{CE}^{2}+(\mathrm{BD}+\mathrm{DE})^{2} \ldots$ (iv).

Kemudian, persamaan (i) disbutitusikan ke dalam persamaan (iv), sehingga diperoleh:

$\mathrm{BC}^{2}=\mathrm{CD}^{2}-\mathrm{DE}^{2}+(\mathrm{BD}+\mathrm{DE})^{2}$

$\mathrm{BC}^{2}=\mathrm{CD}^{2}-\mathrm{DE}^{2}+\mathrm{BD}^{2}+2 \cdot \mathrm{BD} \cdot \mathrm{DE}+\mathrm{DE}^{2}$

$\mathrm{BC}^{2}=\mathrm{CD}^{2}+\mathrm{BD}^{2}+2 \cdot \mathrm{BD} . \mathrm{DE} \ldots(\mathrm{v})$

Berdasarkan penjabaran di atas, diperoleh persamaan (v). Selanjutnya, persamaan (iii) di atas dikalikan dengan BD pada kedua ruas, sedangkan persamaan (v) dikalikan dengan AD pada kedua ruas. Hal ini mengakibatkan muncul dua persamaan baru, yaitu persamaan (vi) dan persamaan (vii) sebagai berikut:

$$
\begin{aligned}
& \mathrm{AC}^{2} \cdot \mathrm{BD}=\mathrm{CD}^{2} \cdot \mathrm{BD}+\mathrm{AD}^{2} \cdot \mathrm{BD}-2 \cdot \mathrm{AD} \cdot \mathrm{DE} \cdot \mathrm{BD} \ldots \text { (vi). } \\
& \mathrm{BC}^{2} \cdot \mathrm{AD}=\mathrm{CD}^{2} \cdot \mathrm{AD}+\mathrm{BD}^{2} \cdot \mathrm{AD}+2 \cdot \mathrm{BD} \cdot \mathrm{DE} \cdot \mathrm{AD} \ldots \text { (vii). }
\end{aligned}
$$

Persamaan (vi) dan (vii) tersebut kita jumlahkan, sehingga menghasilkan persamaan sebagai berikut.

$A C^{2} \cdot B D+B C^{2} \cdot A D=C D^{2} .(A D+B D)+A D \cdot B D \cdot(A D+B D)$.

Karena $A D+B D=A B$, sehingga persamaan di atas dapat disederhanakan menjadi: 
$\mathrm{AC}^{2} \cdot \mathrm{BD}+\mathrm{BC}^{2} \cdot \mathrm{AD}=\mathrm{CD}^{2} \cdot \mathrm{AB}+\mathrm{AD} \cdot \mathrm{BD} \cdot \mathrm{AB}$.

Dengan sedikit manipulasi, maka diperoleh: $C D^{2} \times A B=B C^{2} \times A D+A C^{2} \times B D-$ $A D \times B D \times A B$

Dengan demikian, dapat ditunjukkan bahwa pada segitiga $\mathrm{ABC}$ berlaku persamaan

$$
C D^{2} \times A B=B C^{2} \times A D+A C^{2} \times B D-A D \times B D \times A B
$$

\section{Hasil Pengumpulan Data}

Pada saat mahasiswa bekerja untuk menentukan pembuktian dari teorema Stewart, peneliti mengusahakan membuat kondisi menjadi senyaman mungkin. Hasil dari proses pengumpulan data berupa dokumen lembar jawaban yang berisi proses pembuktian teorema Stewart yang dilakukan oleh mahasiswa. Proses pengumpulan data ini didokumentasikan dengan rekaman CCTV. Pada pembahasan ini akan disampaikan proses pembuktian teorema Stewart yang dilakukan mahasiswa hasil dari analisis pada lembar jawaban yang dilakukan oleh peneliti. Proses pembuktian teorema Stewart yang dilakukan oleh masing-masing mahasiswa diuraikan sebagai berikut:

\section{Mahasiswa Pertama (YH)}

Berdasarkan yang tertulis pada lembar jawaban, mahasiswa memulai dengan menggambarkan segitiga ABC seperti yang tergambar pada lembar soal, tetapi menambahkan garis penghubung $\mathrm{CE}$ yang merupakan tinggi dari segitiga $\mathrm{ABC}$.

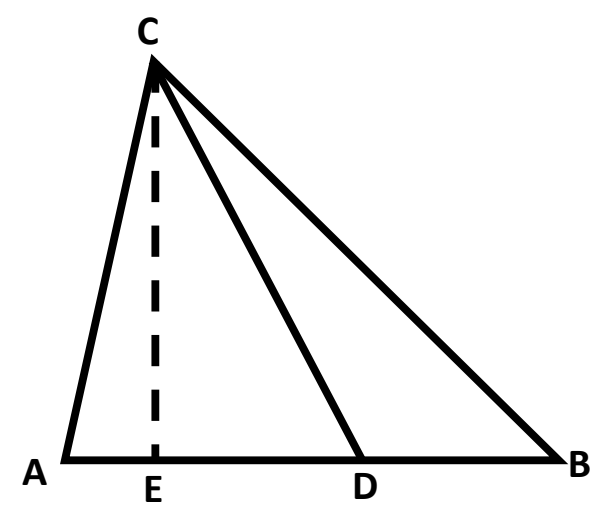

\section{Gambar 3. Segitiga ABC yang digambarkan oleh YH}

Selanjutnya, mahasiswa ini menggunakan torema phytaghoras untuk segitiga siku-siku CDE, BCE, dan ACE sebagai berikut:

$\mathrm{CD}^{2}=\mathrm{DE}^{2}+\mathrm{CE}^{2}$ yang dinamai dengan persamaan (1)

$\mathrm{CB}^{2}=\mathrm{BE}^{2}+\mathrm{CE}^{2}$ dinamai dengan persamaan (2)

$\mathrm{AC}^{2}=\mathrm{AE}^{2}+\mathrm{CE}^{2}$ dinamai dengan persamaan (3)

Kemudian pada persamaan (1), ruas kiri dan ruas kanan dikalikan dengan panjang garis $\mathrm{AB}$, sehingga diperoleh bentuk:

$\mathrm{CD}^{2} \cdot \mathrm{AB}=\mathrm{DE}^{2} \cdot \mathrm{AB}+\mathrm{CE}^{2} . \mathrm{AB}$.

Diketahui pada gambar bahwa panjang $\mathrm{AB}=\mathrm{AD}+\mathrm{BD}$, sehingga bentuk persamaan tersebut dapat dirubah menjadi: 
$\mathrm{CD}^{2} \cdot \mathrm{AB}=\mathrm{DE}^{2} \cdot(\mathrm{AD}+\mathrm{BD})+\mathrm{CE}^{2} \cdot(\mathrm{AD}+\mathrm{BD})$

$\mathrm{CD}^{2} \cdot \mathrm{AB}=\mathrm{DE}^{2} \cdot \mathrm{AD}+\mathrm{DE}^{2} \cdot \mathrm{BD}+\mathrm{CE}^{2} \cdot \mathrm{AD}+\mathrm{CE}^{2} \cdot \mathrm{BD}$

Setelah itu, persamaan (3) dirubah menjadi: $\mathrm{CE}^{2}=\mathrm{AC}^{2}-\mathrm{AE}^{2}$ dan disubtitusikan ke dalam persamaan $\mathrm{CD}^{2} \cdot \mathrm{AB}=\mathrm{DE}^{2} \cdot \mathrm{AD}+\mathrm{DE}^{2} \cdot \mathrm{BD}+\mathrm{CE}^{2} \cdot \mathrm{AD}+\mathrm{CE}^{2} \cdot \mathrm{BD}$, sehingga diperoleh bentuk: $\mathrm{CD}^{2} . \mathrm{AB}=\mathrm{DE}^{2} . \mathrm{AD}+\mathrm{DE}^{2} \cdot \mathrm{BD}+\mathrm{AC}^{2} \cdot \mathrm{AD}-\mathrm{AE}^{2} \cdot \mathrm{AD}+\mathrm{AC}^{2} \cdot \mathrm{BD}-$ $\mathrm{AE}^{2}$. BD dinamai dengan persamaan (4). Untuk selanjutnya, persamaan (2) dirubah menjadi: $\mathrm{BE}^{2}=\mathrm{CB}^{2}-\mathrm{CE}^{2}$. Oleh karena panjang $\mathrm{BE}=\mathrm{DE}+\mathrm{BD}$, maka persamaan $\mathrm{BE}^{2}=\mathrm{CB}^{2}-\mathrm{CE}^{2}$ ekuivalen dengan bentuk: $(\mathrm{DE}+\mathrm{BD})^{2}=\mathrm{BC}^{2}-\mathrm{CE}^{2}$. Persamaan ini kemudian diuraikan sehingga diperoleh: $\mathrm{DE}^{2}+2 . \mathrm{DE} . \mathrm{BD}+\mathrm{BD}^{2}=\mathrm{BC}^{2}-\mathrm{CE}^{2} \Leftrightarrow \mathrm{DE}^{2}=\mathrm{BC}^{2}-\mathrm{CE}^{2}-2 . \mathrm{DE}$. $\mathrm{BD}-\mathrm{BD}^{2}$, persamaan ini dinamai dengan persamaan (5).

Persamaan (5) tersebut disubtitusikan ke dalam persamaan (4), hal ini diuraikan sebagai berikut:

$$
\begin{aligned}
& \mathrm{CD}^{2} \cdot \mathrm{AB}=\mathrm{DE}^{2} \cdot \mathrm{AD}+\mathrm{DE}^{2} \cdot \mathrm{BD}+\mathrm{AC}^{2} \cdot \mathrm{AD}-\mathrm{AE}^{2} \cdot \mathrm{AD}+\mathrm{AC}^{2} \cdot \mathrm{BD}-\mathrm{AE} \mathrm{E}^{2} \cdot \mathrm{BD}
\end{aligned}
$$

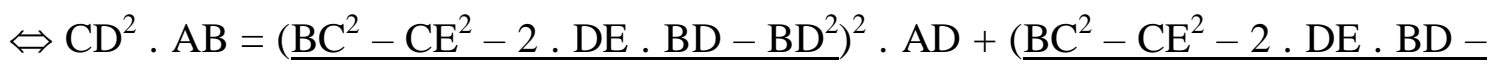
$\left.\underline{\mathrm{BD}^{2}}\right)^{2} \cdot \mathrm{BD}+\mathrm{AC^{2 }} \cdot \mathrm{AD}-\mathrm{AE}^{2} \cdot \mathrm{AD}+\mathrm{AC} \mathrm{C}^{2} \cdot \mathrm{BD}-\mathrm{AE}^{2} \cdot \mathrm{BD}$.

$\Leftrightarrow \mathrm{CD}^{2} \cdot \mathrm{AB}=\underline{\mathrm{BC}} \mathrm{C}^{2} \cdot \mathrm{AD}-\mathrm{CE}^{2} \cdot \mathrm{AD}-2 \cdot \mathrm{DE} \cdot \mathrm{BD} \cdot \mathrm{AD}-\mathrm{BD}^{2} \cdot \mathrm{AD}+\underline{\mathrm{BC}} \mathrm{C}^{2} \cdot \mathrm{BD}-\mathrm{CE} \mathrm{E}^{2}$ $\mathrm{BD}-2 \cdot \mathrm{DE} \cdot \mathrm{BD}^{2}-\mathrm{BD}^{2} \cdot \mathrm{BD}+\mathrm{AC}^{2} \cdot \mathrm{AD}-\mathrm{AE}^{2} \cdot \mathrm{AD}+\mathrm{AC}^{2} \cdot \mathrm{BD}-\mathrm{AE} E^{2} \cdot \mathrm{BD}$.

Terdapat kekeliruan pada penjabaran bentuk yang digaris bawah. Bentuk $\left(\underline{\mathrm{BC}^{2}-\mathrm{CE}^{2}-}\right.$

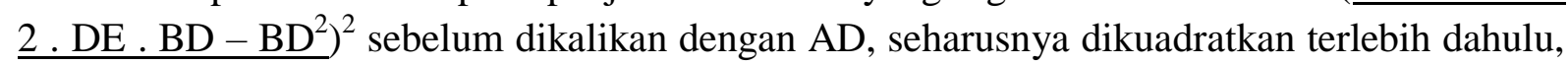
namun pada penjabaran selanjutnya bentuk tersebut tidak dikuadratkan dan langsung dikalikan dengan $\mathrm{AD}$ sehingga menjadi bentuk $\mathrm{BC}^{2} . \mathrm{AD}-\mathrm{CE}^{2} . \mathrm{AD}-2$. DE . BD . $\mathrm{AD}-$ $\mathrm{BD}^{2}$. AD. Berdasarkan hal ini, penyajian kelanjutan proses pembuktian teorema Stewart yang dilakukan mahasiswa ini tidak dituliskan oleh peneliti. Pada akhirnya mahasiswa ini belum berhasil membuktikan teorema Stewart.

\section{Mahasiswa Kedua $(\mathrm{H})$}

Dari yang tertulis pada lembar jawaban, mahasiswa menuliskan bahwa persamaan dengan bentuk $C D^{2} \cdot A B=B C^{2} \cdot A D+A C^{2} \cdot B D-A D \cdot B D \cdot A B$ merupakan pembuktian satu arah. Oleh sebab itu, mahasiswa ini akan membuktikan persamaan tersebut dengan mengubah bentuk ruas kanan pada persamaan menjadi bentuk ruas kiri. Kemudian, mahasiswa ini menggambarkan sebuah garis bantu pada segitiga $\mathrm{ABC}$, yaitu garis $\mathrm{CE}=\mathrm{h}$ sebagai tinggi dari segitiga $\mathrm{ABC}$.

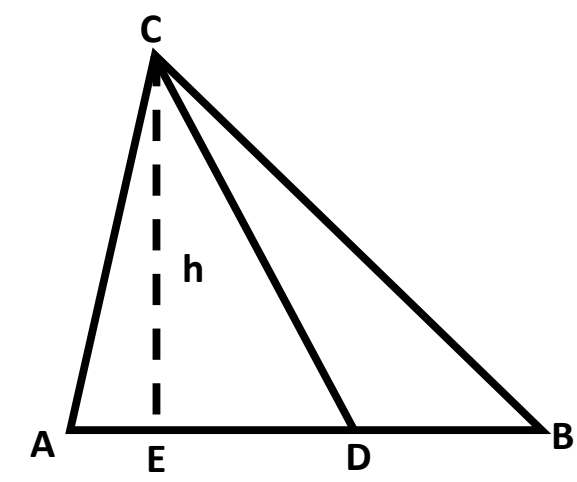

Gambar 4. Segitiga ABC yang digambar oleh H 
Selanjutnya dari gambar di atas, diperoleh bahwa panjang $\mathrm{AD}=\mathrm{AB}-\mathrm{BD}$ dan $\mathrm{AE}=\mathrm{AB}$ - $\mathrm{BE}$ serta mengkonstruksikan bentuk $\left(h^{2}+\mathrm{DE}^{2}\right) \cdot \mathrm{AB}=\mathrm{h}^{2} \cdot \mathrm{AB}+\mathrm{DE}^{2} \cdot \mathrm{AB}$. Proses selanjutnya, menggunakan teorema pythagoras pada segitiga siku-siku BCE, CDE dan segitiga siku-siku ACE, diperoleh:

$$
\begin{aligned}
& \mathrm{BC}^{2}=\mathrm{CE}^{2}+\mathrm{BE}^{2} \Leftrightarrow \mathrm{BC}^{2}=\mathrm{h}^{2}+\mathrm{BE}^{2}, \\
& \mathrm{CD}^{2}=\mathrm{CE}^{2}+\mathrm{DE}^{2} \Leftrightarrow \mathrm{CD}^{2}=\mathrm{h}^{2}+\mathrm{DE}^{2}, \text { dan } \\
& \mathrm{AC}^{2}=\mathrm{CE}^{2}+\mathrm{AE}^{2} \Leftrightarrow \mathrm{AC}^{2}=\mathrm{h}^{2}+\mathrm{AE}^{2} .
\end{aligned}
$$

Setelah semua informasi di atas diperoleh, mahasiswa ini menguraikan bentuk ruas kanan, yaitu $B C^{2} \cdot A D+A C^{2} \cdot B D-A D \cdot B D \cdot A B$ menjadi $C D^{2} \cdot A B$. Proses penguraian tersebut dijabarkan sebagai berikut:

$$
\begin{aligned}
& B C^{2} \cdot A D+A C^{2} \cdot B D-A D \cdot B D \cdot A B=C D^{2} \cdot A B \\
& \Leftrightarrow\left(h^{2}+B E^{2}\right) \cdot A D+\left(h^{2}+A E^{2}\right) \cdot B D-A D \cdot B D \cdot A B=C D^{2} \cdot A B
\end{aligned}
$$

oleh karena $\mathrm{AD}=\mathrm{AB}-\mathrm{BD}$, sehingga diperoleh bentuk yang ekuivalen dengan persamaan di atas sebagai berikut:

$$
\begin{aligned}
& \Leftrightarrow\left(h^{2}+B E^{2}\right) \cdot(A B-B D)+\left(h^{2}+A E^{2}\right) \cdot B D-A D \cdot B D \cdot A B=C D^{2} \cdot A B \\
& \Leftrightarrow h^{2} \cdot A B-h^{2} \cdot B D+B E^{2} \cdot A B-B E^{2} \cdot B D+h^{2} \cdot B D+A E^{2} \cdot B D-A D \cdot B D \cdot A B=
\end{aligned}
$$
$\mathrm{CD}^{2} . \mathrm{AB}$

$$
\begin{aligned}
& \Leftrightarrow h^{2} \cdot A B+B E^{2} \cdot A B-B E^{2} \cdot B D+A E^{2} \cdot B D-A D \cdot B D \cdot A B=C D^{2} \cdot A B \\
& \Leftrightarrow h^{2} \cdot A B+B E^{2} \cdot(A B-B D)+A E^{2} \cdot B D-A D \cdot B D \cdot A B=C D^{2} \cdot A B \\
& \Leftrightarrow h^{2} \cdot A B+B E^{2} \cdot A D+A E^{2} \cdot B D-A D \cdot B D \cdot A B=C D^{2} \cdot A B \\
& \Leftrightarrow h^{2} \cdot A B+B E^{2} \cdot A D+A E^{2} \cdot B D-(A B-B D) \cdot B D \cdot A B=C D^{2} \cdot A B \\
& \Leftrightarrow h^{2} \cdot A B+B E^{2} \cdot A D+A E^{2} \cdot B D-A B^{2} \cdot B D+B D^{2} \cdot A B=C D^{2} \cdot A B
\end{aligned}
$$

Dari informasi yang diperoleh pada bagian awal, diketahui bahwa $\mathrm{AE}=\mathrm{AB}-\mathrm{BE}$, sehingga persamaan di atas ekuivalen dengan persamaan:

$$
\begin{aligned}
& \Leftrightarrow h^{2} \cdot A B+B E^{2} \cdot A D+(A B-B E)^{2} \cdot B D-A B^{2} \cdot B D+B D^{2} \cdot A B=C D^{2} \cdot A B \\
& \Leftrightarrow h^{2} \cdot A B+B E^{2} \cdot A D+\left(A B^{2}-2 \cdot A B \cdot B E+B E^{2}\right) \cdot B D-A B^{2} \cdot B D+B D^{2} \cdot A B=
\end{aligned}
$$
$\mathrm{CD}^{2} \cdot \mathrm{AB}$

$$
\Leftrightarrow h^{2} \cdot A B+B E^{2} \cdot A D+A B^{2} \cdot B D-2 \cdot A B \cdot B E \cdot B D+B E^{2} \cdot B D-A B^{2} \cdot B D+B D^{2} .
$$
$\mathrm{AB}=\mathrm{CD}^{2} \cdot \mathrm{AB}$

$$
\begin{aligned}
& \Leftrightarrow h^{2} \cdot A B+B E^{2} \cdot A D-2 \cdot A B \cdot B E \cdot B D+B E^{2} \cdot B D+B D^{2} \cdot A B=C D^{2} \cdot A B \\
& \Leftrightarrow h^{2} \cdot A B+B E^{2} \cdot(A D+B D)-2 \cdot A B \cdot B E \cdot B D+B D^{2} \cdot A B=C D^{2} \cdot A B \\
& \Leftrightarrow h^{2} \cdot A B+B E^{2} \cdot A B-2 \cdot A B \cdot B E \cdot B D+B D^{2} \cdot A B=C D^{2} \cdot A B \\
& \Leftrightarrow h^{2} \cdot A B+\left(B E^{2}-2 \cdot B E \cdot B D+B D^{2}\right) \cdot A B=C D^{2} \cdot A B \\
& \Leftrightarrow h^{2} \cdot A B+(B E-B D)^{2} \cdot A B=C D^{2} \cdot A B
\end{aligned}
$$

Pada gambar dapat diketahui dengan jelas bahwa panjang $\mathrm{DE}=\mathrm{BE}-\mathrm{BD}$, sehingga persamaan di atas ekuivalen dengan:

$$
\Leftrightarrow \mathrm{h}^{2} \cdot \mathrm{AB}+\mathrm{DE}^{2} \cdot \mathrm{AB}=\mathrm{CD}^{2} \cdot \mathrm{AB}
$$

telah dikonstruksikan di atas bahwa bentuk $h^{2} . A B+D E^{2} . A B=C D^{2} . A B$, sehingga diperoleh: $C^{2} . A B=C D^{2}$. AB. Sehingga dengan kata lain, ruas kanan sama dengan ruas kiri. Mahasiswa ini dapat membuktikan teorema Stewart dengan proses panjang. 


\section{Mahasiswa Ketiga (DF)}

Mahasiswa ini memulai membuktikan teorema Stewart dengan menguraikan persamaan $C D^{2} \cdot A B=B C^{2} \cdot A D+A C^{2} \cdot B D-A D \cdot B D \cdot A B$ menjadi bentuk $\mathrm{CD}^{2} \cdot \mathrm{AB}=\mathrm{BC}^{2} \cdot(\underline{\mathrm{AB}}-\mathrm{BD})$ $+\mathrm{AC}^{2} . \mathrm{BD}-\mathrm{AD}$. BD . AB. Bentuk $\mathrm{AB}-\mathrm{BD}$ diperoleh dari gambar segitiga $\mathrm{ABC}$ yang tercantum pada lembar soal, sebagai berikut:

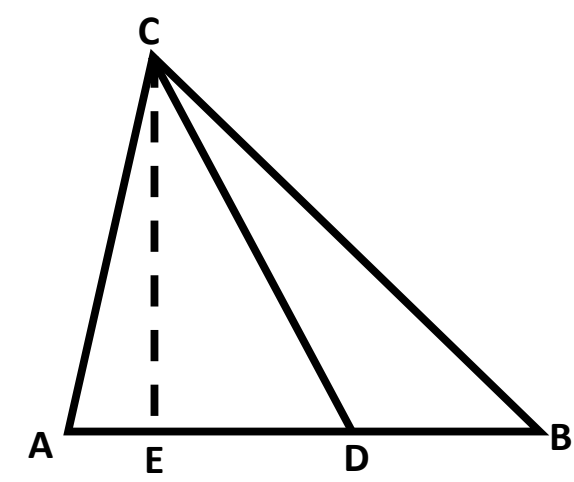

\section{Gambar 5. Segitiga $\mathrm{ABC}$ yang digambar oleh $\mathrm{DF}$}

Terlihat pada gambar di atas, bahwa panjang $\mathrm{AD}=\mathrm{AB}-\mathrm{BD}$. Kemudian, bentuk $\mathrm{CD}^{2}$. $\mathrm{AB}=\mathrm{BC}^{2} .(\mathrm{AB}-\mathrm{BD})+\mathrm{AC}^{2} . \mathrm{BD}-\mathrm{AD} . \mathrm{BD} . \mathrm{AB}$ diuraikan lagi, sehingga diperoleh:

$\mathrm{CD}^{2} \cdot \mathrm{AB}=\mathrm{BC}^{2} \cdot \mathrm{AB}-\mathrm{BC}^{2} \cdot \mathrm{BD}+\mathrm{AC}^{2} \cdot \mathrm{BD}-\mathrm{AD} \cdot \mathrm{BD} \cdot \mathrm{AB}$

$\Leftrightarrow C D^{2} \cdot A B-B C^{2} \cdot A B=\left(A C^{2}-B C^{2}\right) \cdot B D-A D \cdot B D \cdot A B$

$\Leftrightarrow\left(\mathrm{CD}^{2}-\mathrm{BC}^{2}\right) \cdot \mathrm{AB}=\left(\mathrm{AC}^{2}-\mathrm{BC}^{2}\right) \cdot \mathrm{BD}-\mathrm{AD} \cdot \mathrm{BD} \cdot \mathrm{AB}$

Selanjutnya mensubtitusikan bentuk $A D=A B-B D$ ke dalam persamaan di atas, sehingga diperoleh persamaan dengan bentuk:

$$
\begin{aligned}
& \left(C D^{2}-B^{2}\right) \cdot A B=\left(A C^{2}-B^{2}\right) \cdot B D-(A B-B D) \cdot B D \cdot A B \\
& \Leftrightarrow\left(C D^{2}-B^{2}\right) \cdot A B=\left(A C^{2}-B C^{2}\right) \cdot B D-A B^{2} \cdot B D+B D^{2} \cdot A B \\
& \Leftrightarrow\left(C^{2}-B^{2}\right) \cdot A B-B D^{2} \cdot A B=\left(A C^{2}-B^{2}\right) \cdot B D-A B^{2} \cdot B D \\
& \Leftrightarrow\left(C^{2}-B^{2}-B D^{2}\right) \cdot A B=\left(A C^{2}-B^{2}-A B^{2}\right) \cdot B D
\end{aligned}
$$

Dari bentuk persamaan di atas, mahasiswa ini menyimpulkan bahwa: $\frac{C D^{2}}{A C^{2}}=\frac{B D}{A B}$; $\frac{B C^{2}}{B C^{2}}=\frac{B D}{A B} ; \frac{B D^{2}}{A B^{2}}=\frac{B D}{A B}$. Kesimpulan ini secara matematis tidak bisa diterima, karena secara matematis bentuk $\left(\mathrm{CD}^{2}-\mathrm{BC}^{2}-\mathrm{BD}^{2}\right) \cdot \mathrm{AB}=\left(\mathrm{AC}^{2}-\mathrm{BC}^{2}-\mathrm{AB}^{2}\right)$. BD ekuivalen dengan $\frac{\left(C D^{2}-B C^{2}-B D^{2}\right)}{\left(A C^{2}-B C^{2}-A B^{2}\right)}=\frac{B D}{A B}$ dan dengan proses yang bagaimanapun tidak akan dapat disimpulkan bahwa $\frac{C D^{2}}{A C^{2}}=\frac{B D}{A B} ; \frac{B C^{2}}{B C^{2}}=\frac{B D}{A B} ; \frac{B D^{2}}{A B^{2}}=\frac{B D}{A B}$. Karena terdapat kekeliruan yang tidak bisa diterima, sehingga penyajian kelanjutan proses pembuktian teorema Stewart yang dilakukan oleh mahasiswa tidak dituliskan oleh peneliti. Pada akhirnya mahasiswa ini belum dapat membuktikan teorema Stewart.

\section{Diskusi dan Pembahasan}

Dengan demikian, masing-masing mahasiswa telah mencoba untuk membuktikan teorema Stewart. Namun, hanya mahasiswa kedua yang dapat menyelesaikan pembuktian teorema Stewart dengan proses yang panjang. Jika diamati lebih lanjut, proses pembuktian 
yang dilakukan oleh ketiga mahasiswa ini menggunakan metode pembuktian langsung. Langkah-langkah yang dilakukan oleh tiga mahasiswa ini berbeda-beda, tetapi terdapat beberapa kesamaan, yaitu terlebih dahulu menggambarkan segitiga ABC dan menambahkan garis tinggi $\mathrm{CE}$, menggunakan sifat-sifat garis tinggi dan teorema phytagotas untuk mencari informasi yang digunakan dalam pembuktian.

Dari proses pembuktian yang dilakukan oleh mahasiswa pertama, dapat disimpulkan bahwa mahasiswa pertama kurang teliti pada saat menguraikan bentuk $\left(\mathrm{BC}^{2}-\mathrm{CE}^{2}-2\right.$. $\mathrm{DE}$. $\left.\mathrm{BD}-\mathrm{BD}^{2}\right)^{2}$, sehingga terjadi kekeliruan fatal pada proses-proses selanjutnya. Begitu juga dengan proses pembuktian yang dilakukan oleh mahasiswa ketiga. Pada proses pembuktian yang dilakukan oleh mahasiswa ketiga terjadi kekeliruan dalam menyimpulkan bentuk $\left(\mathrm{CD}^{2}-\right.$ $\left.\mathrm{BC}^{2}-\mathrm{BD}^{2}\right) \cdot \mathrm{AB}=\left(\mathrm{AC}^{2}-\mathrm{BC}^{2}-\mathrm{AB}^{2}\right) . \mathrm{BD}$. Hal ini mungkin disebabkan karena mahasiswa ketiga kurang memahami konsep aljabar dari suatu bilangan.

Kekeliruan seperti ini mungkin tidak akan terjadi jika mahasiswa diberi waktu yang lebih lama pada saat mencoba membuktikan, karena setiap orang mempunyai kecepatan berbeda-beda dalam menyelesaikan suatu permasalahan. Sehingga selain mempunyai pemikiran yang kritis, analitis, logis dan sistematis, seseorang juga harus mempunyai keterampilan pemecahan masalah.

\section{Hasil Temuan}

Berdasarkan uraian pada bagian diskusi dan pembahasan di atas, ditemukan beberapa hal penting berkaitan dengan pembuktian teorema Stewart, antara lain proses pembuktian yang dilakukan oleh ketiga mahasiswa tersebut menggunakan metode pembuktian langsung, terdapat beberapa kesamaan ketiga mahasiswa dalam mengawali proses pembuktian, yaitu: menggambar garis tinggi pada segitiga, dan menggunakan teorema pythagoras untuk menambah informasi yang digunakan dalam proses pembuktian, untuk membuktikan teorema Stewart dibutuhkan ketelitian pada saat menguraikan suatu bentuk aljabar dan pemahaman terhadap konsep aljabar dari bilangan, untuk membuktikan teorema Stewart dibutuhkan waktu yang sesuai dengan kecepatan berpikir yang membuktikan, untuk membuktikan teorema Stewart dibutuhkan keterampilan pemecahan masalah, pemikiran logis, kritis, analitis dan sistematis.

\section{Kesimpulan}

Berdasarkan penjelasan-penjelasan pada bagian sebelumnya, pada penelitian dapat disimpulkan bahwa secara garis besar langkah-langkah pembuktian teorema Stewart yang dilakukan oleh mahasiswa semester VI, Program Studi Pendidikan Matematika, Universitas Katolik Widya Mandala Madiun, yaitu menggambar segitiga ABC dan menggambarkan pula garis bantu yaitu, garis tinggi $\mathrm{CE}$, mengumpulkan informasi-informasi yang digunakan dalam proses pembuktian, menggunakan informasi-informasi yang diperoleh untuk menguraikan bentuk ruas kanan dari persamaan $C D^{2} \cdot A B=B C^{2} \cdot A D+A C^{2} \cdot B D-A D \cdot B D \cdot A B$ menjadi ruas kiri, sehingga persamaan tersebut berlaku. 


\section{Daftar Pustaka}

Arieyantini, P. (2013). Logika Matematika. Retrieved September 21, 2018, from http://pramanikaarieyantini.blogspot.com/2013/01/logika-matematika_10.html.

Bartle, R. G. \& D. R. S. (1994). Introduction to Real Analysis (Second). Singapore: John Wiley \& Son (SEA), Inc.

Hernadi, J. (2012). Metoda Pembuktian dalam Matematika. Retrieved September 21, 2018, from https://julanhernadi.files.wordpress.com/2012/11/method-of-proof.pdf

Kristanto, V. H. (2011). Pendidikan Karakter dalam Pembelajaran Matematika Pembentuk Generasi Anti Korupsi. Jurnal Widya Warta, Tahun XXXV(01), 140-141.

Liu, C. L. (1995). Dasar-dasar Matematika Diskrit (Edisi Kedu). Jakarta: PT Gramedia Pustaka Utama. 